\title{
Life-threatening gastrointestinal haemorrhage from a large Meckel's diverticulum
}

\author{
Peter G Vaughan-Shaw, ${ }^{1}$ Simon Dwerryhouse ${ }^{2}$
}

${ }^{1}$ Department of Surgery, Gloucester Royal Hospital, Gloucester, UK ${ }^{2}$ Department of Upper GI Surgery, Gloucester Royal Hospital, Gloucester, UK

\section{Correspondence to} Mr Peter Vaughan-Shaw, pvaughan-shaw@nhs.net
To cite: Vaughan-Shaw PG, Dwerryhouse S. BMJ Case Rep Published online: [please include Day Month Year] doi:10.1136/bcr-2012008441

\section{DESCRIPTION}

A 16-year-old patient was admitted to the emergency department one morning following a collapse with a short history of haematochezia (bleeding per rectum). There was no history of trauma or change in bowel habit and no relevant medical history or drug history. On admission, haemoglobin was $95 \mathrm{~g} / \mathrm{l}$. The patient was tachycardic (heart rate 140 beats/min), and hypotensive (blood pressure $85 / 60 \mathrm{~mm} \mathrm{Hg}$ ) but responded well to initial resuscitation with intravenous crystalloid and 2 units of packed red blood cells. As the patient had stabilised, a CT angiography scan of the abdomen was performed but showed no evidence of active bleeding, a previous bleeding site or any other pathology. The patient was transferred to the intensive care unit for close monitoring and further crystalloid and red blood cell transfusion. The decision was made to observe the patient overnight and perform a technetium $\mathrm{Tc} 99 \mathrm{~m}$ scan the following morning to determine whether a Meckel's diverticulum was present. However, during the course of the evening, the patient passed a further $400 \mathrm{ml}$ of dark rectal blood. Haemoglobin dropped from $102 \mathrm{~g} / \mathrm{l}$, after a total of 4 units of packed red cells, to $69 \mathrm{~g} / \mathrm{l}$ and the patient became haemodynamically unstable with a blood pressure of 75/40 and heart rate of 115. A decision was made to proceed to laparotomy. On laparotomy, a $20 \mathrm{~cm}$ Meckel's

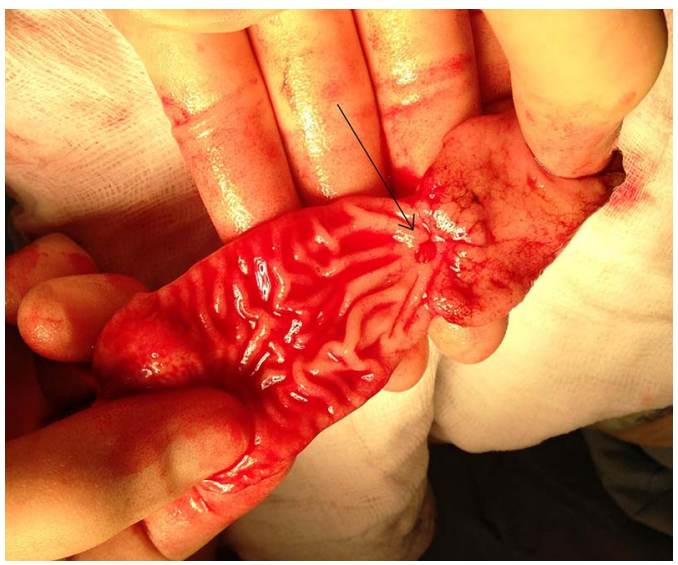

Figure 1 Excised Meckel's diverticulum (intraluminal view) with visible omphalomesenteric (vitelline) artery (arrowed).

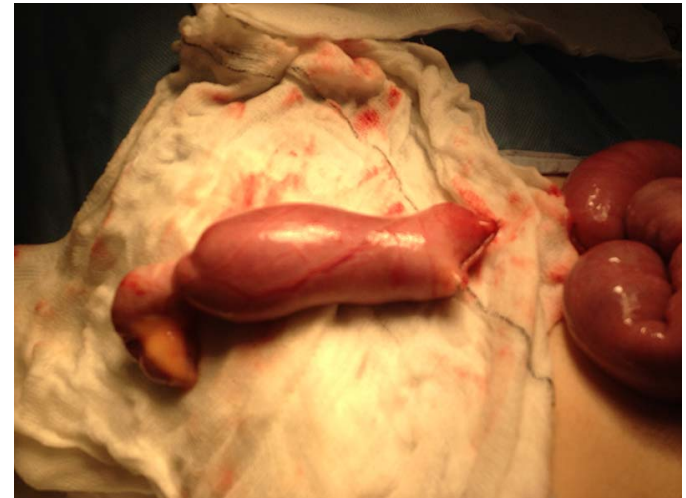

Figure 2 Excised Meckel's diverticulum (external).

diverticulum was found approximately $80 \mathrm{~cm}$ from the ileocaecal valve and was excised with a limited small bowel resection and stapled anastomosis. On opening the specimen, the diverticulum was full of fresh blood with visible ectopic gastric mucosa and omphalomesenteric artery (figures 1 and 2). Postoperatively, the patient made an uncomplicated recovery and was discharged 4 days later.

\section{Learning points}

- Gastrointestinal haemorrhage is rare in adolescent males but may represent bleeding from a Meckel's diverticulum. ${ }^{1}$

- Haemodynamic compromise in children and adolescents occurs late and indicates significant intravascular volume depletion.

- Major gastrointestinal haemorrhage with haemodynamic instability should prompt consideration of urgent intervention by endoscopic, radiological or surgical means.

Competing interests None.

Patient consent Obtained.

Provenance and peer review Not commissioned; externally peer reviewed.

\section{REFERENCE}

1 Sagar J, Kumar V, Shah DK. Meckel's diverticulum: a systematic review. J $R$ Soc Med 2006:99:501-5. 
Copyright 2013 BMJ Publishing Group. All rights reserved. For permission to reuse any of this content visit http://group.bmj.com/group/rights-licensing/permissions.

BMJ Case Report Fellows may re-use this article for personal use and teaching without any further permission.

Become a Fellow of BMJ Case Reports today and you can:

- Submit as many cases as you like

- Enjoy fast sympathetic peer review and rapid publication of accepted articles

- Access all the published articles

- Re-use any of the published material for personal use and teaching without further permission

For information on Institutional Fellowships contact consortiasales@bmjgroup.com

Visit casereports.bmj.com for more articles like this and to become a Fellow 